\title{
In All Seriousness: Humour in Adibah Amin's As I was Passing and As I was Passing II
}

\author{
*FARAH AKMAR \\ MOHAMMAD A. QUAYUM \\ MADIHA RAMLAN
}

Department of English Language and Literature, Kuliyyah of Islamic Revealed Knowledge and Human Sciences, International Islamic University Malaysia, 53100 Kuala Lumpur, Malaysia

*Corresponding author: farah.akmar@yahoo.com

Published online: 26 September 2018

To cite this article: Akmar, F., Quayum, M.A. and Ramlan, M. 2018. In all seriousness: Humour in Adibah Amin's As I was Passing and As I was Passing II. KEMANUSIAAN the Asian Journal of Humanities 25(2): 23-47, https://doi.org/10.21315/kajh2018.25.2.2

To link to this article: https://doi.org/10.21315/ kajh2018.25.2.2

\begin{abstract}
This paper investigates Adibah Amin's use of humour in the two volumes of her occasional writing, As I was Passing (2007). To pursue this objective, the theory of humour formulated by John Morreall, a renowned contemporary figure in humour studies, has been used to frame the discussion. However, since Morreall focuses mostly on spoken humour, the paper also makes references to Dominic Cheetam's work on written humour. The analysis shows that some elements fundamental to humour that can be found in Adibah Amin's writing are the presence of cognitive shifts that involve expectations and violation thereof, the play mode that induces practical disengagement, and the sense of enjoyment that is exhilarating and liberating. Furthermore, Adibah Amin uses humour to promote intellectual and moral values. Besides making use of incongruities in things, Adibah Amin also includes some incongruities in presentation in her writing, which deal with her comical adaptations of linguistic patterns, further proving her astute use of humour.
\end{abstract}

Keywords and phrases: Adibah Amin, humour, incongruity, Malaysian literature, written humour

\section{Introduction}

The confounding dissemination of "alternative facts" against the prevailing force of the internet era that exposes people to an inconceivable repository of information, while certainly is not a recent phenomenon, has people increasingly and actively question the integrity of mass media in propagating "truths". The dubiousness of the "reality" presented by the mainstream media nowadays, has been vocally expressed in many forms and one that has escalated in number and gained wider 
recognition, ironically, is comedy. Whereas the humorous representation of human psyche and in general, the world, is not a contemporary invention either, interestingly, its role as a tool to openly resist, question and lambast the mainstream narrative, to encourage critical thinking and discussion, and to pave the way for alternative discursive strategies, has amplified in momentum and has been getting serious recognition. In Malaysia, despite the stringent enforcement of the Sedition Act 1948, Malaysians have never been reticent in communicating disagreements and protests.

Online news portals are abundant and one particular medium that witnesses vibrant manifestations of speech and expression among Malaysians is the social media giant, Facebook. In 2016, it was reported that more than 18 million Malaysians, which exceeded half of the country's population, were on Facebook, thus explaining the opening of Malaysia's Facebook office in the very same year. Nicole Tan, head of the local office, said that "[Malaysian Facebook users] have 60 percent more friends than the global average and spend more time watching videos on their smartphones than consumers in any other country in Southeast Asia" (NST Online 5 May 2016). On Facebook, despite having the crucial need to pay heed to the Sedition Act, Malaysians have proved to be vociferous, both directly and indirectly, in their criticisms of various issues occurring within the country, especially those of politics. What is equally noteworthy is the emergence of Facebook parody accounts among Malaysians that frequently poke fun at the country's current government, politicians, political scandals and social affairs. The people behind these accounts remain mostly anonymous, and yet they have indeed become some of Malaysia's top social influencers, which can be substantiated by the large number of followers each of these accounts has. The frequent jokes and witty criticisms on social and political issues are no longer foreign to Malaysia's virtual landscape and evidently, are also positively accepted by most people. Malaysians' humorous choice of expression however, like the existence of humour itself, is not a newly-invented outlook of life.

In the past, Malaysia's legendary all-rounder, the late Tan Sri P. Ramlee, was (and is still) celebrated for his production of humorous yet critical contents in his films that were reflective of the ongoing political turmoil and incongruous social mores that had been affecting the people negatively. Another renowned figure of humour, is the prominent cartoonist, Mohammad Nor Khalid, or better known as Lat. Famed for his representation of the local culture, particularly that of Malay, Lat comically portrays the good and the bad to which he was exposed while growing up in kampung (village). Humour as a tool to criticise or bring cultural and social idiosyncrasies to light, is not uncommon in Malaysian literature too. The famous Malay folklore collections are replete with amusement and ridicules. "Mat Jenin", 
"Pak Kaduk", "Pak Pandir", "Pak Belalang”, "Lebai Malang” and "Si Luncai” are some of the popular characters with exaggerated whims and farcical desires whose tales never fail to tickle one's funny bone. Beyond the laughter however, the stories reveal criticisms and remarks upon cultural and social absurdities normalised and naturalised in society. The use of humour in Malaysian literature in English on the other hand, is more widespread in journalistic writing. Adibah Amin and Lydia Teh, despite coming from different generations, are known for one similarity their witty and insightful newspaper essays. A significant observation of their writings reveals their adroit application of humour in highlighting and criticising social issues that are prevalent in and perpetuated through day-to-day living.

Representations of reality and society therefore do not necessarily have to affect seriousness, melancholy, gloominess, perplexity or any other emotions sociallydeemed "profound" just to garner attention and consideration. They also do not need to be written in complexity, verbosity and sonority in order to trigger critical thinking on the readers' part. This paper therefore, seeks to focus on the comical representation of people, their lifestyles, habits and customs. This will be achieved by analysing Adibah Amin's selected newspaper essays which have been anthologised into two books entitled, As I was Passing (2007a) and As I was Passing II (2007b). Adibah's essays were selected firstly, for her witty observations and criticisms of society. While most remarks pertaining to her essays always emphasise her sense of humour, the subject of "her use of humour" itself, has never been analysed. The common tendency to read her wittiness purely for its aesthetic value dismisses the possibility of her using humour as a critical strategy. In relation to this, the selection was influenced by the need to emphasise the significance of studying humour in literature. The decision to analyse her writings was also attributed to her marginalised status as a Malaysian writer, which is an utter disservice to her and her insightful works. Our survey has shown that there is very little critical material available on Adibah's writings, with the exception of a chapter in Nor Faridah and Quayum's (2003) book, Colonial to Global; an article on This End of the Rainbow by Kavita Ganesan (2016) and a few scattered items in the local newspapers. It is important that the younger generation, especially school and university students, be exposed to her works in both Malay and English, especially her witty anecdotal pieces in the two volumes of As I was Passing, and be encouraged to study them critically.

\section{Theories of Humour}

Locating humour within Adibah Amin's volumes of As I was Passing is certainly a territory well-trodden. What has been continuously unexplored nonetheless is a critical appraisal of the significance of her humour. It is high time that her jocular 
observation and introspection of everyday lives, which are replete with idiosyncratic and incongruous social norms, be seriously studied. This paper seeks to analyse the ways Adibah renders her anecdotes humorous and her adept use of humour to promote intellectual and moral virtues. In pursuance of these objectives, a humour theory formulated by a renowned contemporary figure in the humour studies, John Morreall, will be used to guide the analysis of the selected texts. Additionally, due to the fact that Morreall's arguments are centred more on spoken humour, this paper will also be considering some points from Dominic Cheetam, who writes about written humour in "Written Humour and Humour Theory" (Cheetam 2003). Prior to explicating the humour and its serious dimension in Adibah's selected texts, this paper will first discuss humour as a theory and its application.

What makes people laugh or find something funny is a highly subjective and relative phenomenon that contemporary studies from various disciplines such as literature, linguistics, education, psychology, sociology, communication and media, have all shown that there is no one universal theory that is able to paint the particularities of humour with a broad brush, thus any attempt to reduce all humorous situations to a specific rule will only make one liable to the sweeping generalisation fallacy. This well-established unanimity nevertheless, could not be reached without reflecting on the historical philosophies of humour, which simplistically, strictly and generally tied humour to their respective systems of thought. Among the major philosophical works on humour that are elaborated and discussed today are the Superiority Theory, the Incongruity Theory and the Relief Theory. Considering the impossibility of generalising the causes of humour as mentioned earlier, it should be foreseeable and understandable by now that these theories are flawed and incomprehensive in their own respective ways, hence the inevitability of criticisms. In spite of this, a discussion on the criticisms put against them will not be attempted in this paper. The summary of these three major theories nonetheless, is crucial to understand the application and the relevance of the theory selected to analyse humour in Adibah Amin's texts, as will be demonstrated later. Additionally, although the three theories are commonly discussed in reference to humour, John Morreall in his book, Taking Laughter Seriously (1983), chooses to view them as "the theories of laughter" instead. According to Morreall (1983), laughter situations are as varied as the factors that make people laugh, and humour merely constitutes one of the situations. Since this paper will adopt his contemporary theory of humour, the three theories mentioned earlier will be discussed in accordance with his view.

The Superiority Theory is based on the notions of the eminent classical figures, Socrates, Plato and Aristotle, which later expanded by Thomas Hobbes, a 17thcentury political philosopher. This theory maintains that people laugh at the 
expense of other people. Indulging in the misfortunes of others with laughter is an aggressive and a derisive form of amusement that exposes people to their base emotion and desire, rendering them irrational and consequently, resulting in the loss of self-control, which runs counter to the paramount importance of rationality that, as according to Plato, is an essential criterion for his concept of the ideal society. One of the best representations of laughing at people's infirmities is the amusement most people find in watching The Three Stooges, an American comedy team famed for their buffoonery and slapstick comedy. The Superiority Theory is then corroborated and developed further by Hobbes who believes that people laugh out of self-glorification having observed or known other people's infirmities. Hobbes asserts that naturally people are competitive thus witnessing "events that show ourselves to be winning, or others losing" is likely to induce a sense of superiority which then leaves us in delight (Morreall 2009, 6). Additionally, according to Hobbes, people can also feel superior to themselves (ibid.). Recognising how we were in the past can make us in the present, amused, hence laughing at ourselves. Echoing the classicists, Hobbes too, does not view humour positively as he maintains that it is merely an expression of a laugher's perceived superiority founded upon the malicious pleasure one experiences while witnessing others' inferiority. What makes his statement slightly different from that of the classicists, and as a matter of fact, germane to the discussion of the theory selected herein, is the inclusion of laughing at our former selves; a present sense of superiority over our inferior past.

The Incongruity Theory is a complete departure from the Superiority Theory. While the proponents of the latter view the amusement derived from humour as purely affective, those of the former on the other hand, perceive it as a cognitive response to an incongruity. Notwithstanding the difference, the Incongruity Theory does not dismiss the role of superior sentiments in laughter. As Morreall explains, the theory first came to light through Aristotle, who hinted that people could laugh when their expectations were overturned by reality:

One way for a speaker to get a laugh [was] to set up a certain expectation in his listeners and then to hit them with something they did not expect ... The same result, Aristotle note[d], [was] also produced by jokes that depend[ed] on a change of spelling or word play $(1983,16)$.

Regardless of this argument, the theory remained undeveloped until the 18th century when Immanuel Kant offered his opinion on laughter. Kant in Critique of Judgement (1892), as cited by Morreall $(1983,16)$, stated that, "laughter [was] an affection arising from the sudden transformation of a strained expectation into nothing [emphasis added]". In the 19th century, Arthur Schopenhauer partially 
refuted Kant by arguing that while undeniably, laughter resulted from our intellectual recognition of incongruity, what ensued from the recognition was not nothing as claimed by Kant. He attributed laughter to the conflict between one's intellectual expectation and perception of reality, and the new-found realisation arising from the perception provided one a distinct way of perceiving and understanding, not nothing. It was something indeed; it simply did not conform to, and in point of fact, contradicted one's preconceived conceptual comprehension. Generally, this idea of finding humour in incongruity, be it from Kant or Schopenhauer, is significant to the formulation of the theory selected for this paper.

The Relief Theory began with Herbert Spencer and was further developed by the notable psychoanalytic theorist, Sigmund Freud. Broadly speaking, this theory holds the notion that, laughter is people's way of releasing their nervous or "psychic" energy. This fundamental principle does not really work against the aforementioned theories. This theory nevertheless, deals with the physiological and psychological dimension of laughter, which renders it more complex than the previous two. Considering this complexity, this paper will not elucidate it in detail, particularly Freud's expansion of it, which involves three different laughter situations. Spencer argued that laughter was a physical manifestation of one's release of nervous energy which was built up prior to laughing; Freud, briefly put, asserted that one laughed to release the existing energy that had been built up and used to suppress socially-prohibited thoughts and feelings in one's mind, particularly those of sexual and violent taboos. The former begins with a situation to build up the nervous energy; the latter requires a situation to trigger and release the existing psychic energy. This theory is vital to describe how people being constantly subjected to depressive or oppressive situations use jokes as an emotional relief; one of their survival mechanisms to cope with the physical and/or mental hardship. "Gallows humour", a form of humour that is rampant among war victims, is one example that aptly reflects the use of humour as a psychological escape from traumatic, hopeless situations. The Relief Theory's focus on the nervous energy and its release is essentially related to the conceptual and perceptual understanding forwarded by the Incongruity Theory. Additionally, the same concern can be linked to the derisive laughter situation from the Superiority Theory. In truth, these three major theories share several similarities that are fundamental to the formulation of the theory selected for this paper. Despite their differences, the three theories remain relevant to the discussion of humour in Adibah Amin's non-fictional volumes, As I was Passing. 


\section{Theoretical Framework}

The theoretical framework of this paper is an expanded version of the Incongruity Theory. The four elements that Morreall includes in Comic Relief: A Comprehensive Philosophy of Humor (2009) to characterise this theory are: the cognitive shift, the play mode, the enjoyment and the laughter. This paper however, will also incorporate some elements of written humour proposed by Dominic Cheetam in "Written Humour and Humour Theory" (2003) considering that Morreall's discussion is significantly focused on spoken humour. Therefore, this paper will not include the fourth aspect of Morreall's theory, which is the laughter, because it is argued that humour found in writing, while pleasant, does not necessarily result in laughter. Prior to elaborating more on written humour, this paper will first discuss three aspects of Morreall's theory of humour. Firstly, the most important aspect of humour is the presence of cognitive shifts, or incongruities in psychological patterns. A cognitive shift consists of "a set-up and a punch" (Morreall 2009, 50). Our standard patterns of understanding and behaviour make up the set-up while "the punch is what causes our thoughts and attitudes to change quickly" (ibid.). In some humour, both the set-up and the punch are included, with the former being the first part of humour and the latter the second; whereas in some, the set-up is expected to be readily available before the punch takes place. In the latter type of humour, the whole humour becomes the punch. Thus, the foundation of humour is made of a transition between two opposite or different mental states; "the greater the contrast between the two states in the cognitive shift, the greater the possible amusement" (Morreall 2009, 51).

Cognitive shifts however, are not always funny or enjoyable. The experience of having our normal mental states of understanding violated unexpectedly is not really comforting as it "threatens our control over what we are doing and what is happening to us" (Morreall 2009, 52). Therefore, what renders some cognitive shifts humorous is the play mode the shifts ignite. While most humour deal with problems, the playful approach it adopts makes people less defensive and let their guard down. There are several ways to establish this play mode: fictionalising, spatial and temporal distancing, and also non-participation. Firstly, when humour presents fictional situations involving fictional characters, no matter how serious the situations are, people are willing to discard the cognitive or practical concerns they normally have for real-life counterparts. Furthermore, the reasons why some real situations can be funny to some people are due to spatial and temporal disengagement. Despite the degree of seriousness some situations pose, the fact that they happened elsewhere or somewhere in the past allows people become morally or physically unconcerned, even if temporarily. Finally, the mere notion that we are not involved in some incongruous yet problematic situations can also 
make us feel amused. All of these ways fundamentally establish a space that allows people to be at ease and remain cognitively or practically disengaged.

The third aspect of humour lies in the sense of enjoyment it triggers. Morreall provides three characteristics of the enjoyment people feel towards humour: "it is social, exhilarating, and liberating" (Morreal 2009, 54). Naturally, people have a higher tendency to laugh together with other people than when they are alone. Although it is not impossible to be amused while being alone, the presence of other people often increases our sense of pleasure. Perhaps, it is difficult to generalise this social enjoyment to written humour due to the nature of the reading activity, which is normally carried out in isolation. Nevertheless, according to Morreall, "even when people began to read printed books privately, they usually thought of themselves as in communication with the author, like people listening to a storyteller" (Morreall 2009, 55). The enjoyment ignited through humour is also exhilarating, in the sense that it induces mental gymnastics in people's thoughts and attitudes. The third element of the enjoyment that people feel towards humour is that it is simply liberating. What is typically forbidden or sensitive in real-life situations can be mocked or questioned in humour: "In the humorous frame of mind, we can challenge any standard belief, value, or convention" (Morreall 2009, $57)$.

It is easier to identify incongruities in spoken humour than in its written counterpart because the cognitive shifts it triggers are faster and brief. For writing to be humorous, the rule of creating punch lines is not applicable. Cognitive shifts that occur having read something funny are usually not immediate. Writers need to sustain readers' attention and expectations and to achieve this, they need to extend humour throughout some portion of the text, if not the whole of it, while making sure that readers will experience both cognitive shifts and amusement repeatedly. Dominic Cheetam's arguments for written humour essentially do not deviate from Morreall's theory of humour, despite some additional points that are not normally associated with spoken humour. Cheetam does not deny the significance of incongruity in written humour, although his notion of incongruity is stretched further as he believes that "conventional views of incongruity tend to be limited, and tend not to include the more gentle, less laugh generating examples of written humour" (Cheetam 2003, 82). This also justifies why Morreall's fourth basic aspect of humour, laughter, is not included in this paper.

It is argued that written humour does not necessarily lead to laughter despite the sense of amusement it creates because it is considered "low key". As a matter of fact, "written humour does not need to make people laugh. It only needs to create a general feeling of humour" (Cheetam 2003, 79). Low key humour requires 
incongruities to be continuous, rather than being isolated or encapsulated with a single punch. The continuity of incongruities in written humour requires writers to be "consistent in the techniques they use to generate humour" to the extent that readers can predict the humour (ibid.). Notwithstanding the predictability and continuity of written humour, it is still able to sustain readers' enjoyment. The most significant points Cheetam offers in the paper lie in his elaboration of incongruity by referring to all humour theories discussed here including Morreall's re-formulation of the Incongruity Theory. He clarifies that conflicts in linguistic or psychological expectations form the foundation of humour and further insists that "incongruity only works if we have expectations" (Cheetam 2003, 82). Examples of incongruities based on expectations that Cheetam includes revolve around adaptations of various linguistic patterns or deviations from standard forms of communication.

To explain the relationship between humour and incongruity further, Cheetam takes the effort to re-evaluate all four theories and present how each of them can contribute to the theory of written humour. In his re-evaluation, he focuses more on the Relief Theory, specifically for its idea on the existence of nervous or psychic energy as proposed by Freud. Cheetam uses a rock analogy to illustrate and discuss the presence of this nervous energy that can eventually be released through laughter:

If we have a rock lying on the side of a hill, then as the rock is not in motion, it might be assumed to have no intrinsic energy. But as soon as something happens to dislodge the rock, we find that it did indeed have a large amount of energy. The energy at rest is called 'potential energy' and the energy in motion is called 'kinetic energy'. Likewise with the human brain. There is no special need to add tension in order to create humour, providing that some form of tension already exists $(2003,87)$.

"Potential energy" is viewed as a metaphorical representation of existing psychological tensions in people's minds. These tensions can be derived from our normal psychological or linguistic expectations and norms. Violations of these expectations and norms, which basically create incongruities, can result in humour. This idea of existing tensions created out of expectations and norms can justify why people laugh out of superiority when we see social status, which normally comes with societal expectations, as a form of social tension.

This very idea of potential energy or existing psychological tension can also explain why minor incongruities in written humour are able to remain humorous despite being repetitive and predictable. Unlike spoken humour that typically relies on a single great punch, the written counterpart makes use of successive 
minor incongruities to create and maintain that cumulative sense of amusement. Naturally, the more normal incongruities become, the less funny they appear as they will be increasingly predictable; if a comedian applies the same techniques to his/her jokes and tell the jokes to the same audience repeatedly, it is highly likely that his/her punch line for the third joke may not be able to induce the same magnitude of laughter from the audience as he/she did with the first two. However, in written humour, minor incongruities are like the rock on the hill:

Even if a rock is repeatedly dislodged, and rolls a little down the hill, if the hill is high enough we can have a lot of little rolls before we reach the bottom. We may get used to the rock rolling, but even so, each time it moves, more of its potential energy is released ... Successive minor points of humour, points which alone are not enough to induce even smiles, when experienced as a sequence, might result in a cumulative effect which we could call 'being amused' (Cheetam 2003, 90-91).

Metaphorically, minor incongruities consist of multiple tensions, which can be released gradually and remain steadily or increasingly funny and "does not become necessarily become less humorous the more we read" (Cheetam 2003, 92).

On the whole, spoken or written, humour principally subverts people's preconceived notions, existing standards or orders, or to put it simply, expectations. Establishing a link between Morreall's and Cheetam's arguments on humour involves comparing their points on expectations and how they can be rendered humorously incongruous. To sum up, Morreall (2009) in describing how cognitive shifts function, argues that "a cognitive shift involves a set-up and a punch. The setup is our background pattern of thoughts and attitudes. The punch is what causes our thoughts and attitudes to change quickly" (50). Meanwhile, Cheetam (2003) states that "incongruity only works if we have expectations" (82) and alludes to linguistic and psychological expectations and norms as the basis of humour. $\mathrm{He}$ also mentions that expectations and norms can be viewed as psychological tensions in people's minds, which can result in humour when released unconventionally. Clearly, humour necessitates two different mental states: expectations (set-up/ psychological tensions) and non-standard realisation of expectations (punch/release of tensions). As stated earlier, expectations can either be included in the initial part of humour or gauged to be readily available in people's minds. Sometimes, both strategies can be applied simultaneously. Hence, the first step to identify humour in Adibah's selected texts is locating and highlighting expectations and the violations thereof, which form the premise of incongruities.

Another objective of this paper is to reveal how Adibah uses humour to express or advocate positive values. Humour, despite requiring the play mode as one of 
its aspects, can be used for serious, beneficial purposes. Morreall (2009) states that fundamentally, "humo[u]r involves the ability to process our perceptions, memories, and imagined ideas in a way that rises above what is real, here, now, personal, and practical" (112). Taking Aristotle's notion of intellectual and moral virtues, Morreall correlates this fundamental ability of humour with these two types of virtue. Intellectually, humour is positive in three ways: promoting openmindedness, encouraging divergent or creative thinking, and also cultivating critical thinking. Firstly, humour is able to question people's existing patterns of thoughts and also to expose them to different perspectives, which then will make them more open to and tolerant of diversity. Through humour too, divergent or creative thinking becomes advanced; "first it blocks negative emotions ... which suppresses creativity by steering thought into familiar channels" and second it provides "a way of appreciating cognitive shifts" as it allows people to be "automatically on the lookout for unusual ideas and new ways of putting ideas together" (Morreall $2009,113)$. Finally, humour fosters critical thinking in the sense that it makes us "look for discrepancies between what people should do, what they say they do, and what they actually do" (ibid.).

The above intellectual virtues can also be linked to the moral virtues of humour. Morally, humour gives rise to self-transcendence. It is able to make people less occupied with their personal concerns and more aware of other people's conditions. The ability to laugh at oneself gives people the opportunity to be objective of themselves and their situations, thus being more rational in dealing with their flaws and problems. Going beyond their "here/now/me" concerns, humour enables people to be more patient, humble, accepting, tolerant, gracious and less defensive, which eventually reduce negative emotions and solve conflicts better. Morreall also includes the moral benefits of humour in traumatic or difficult times which come in three aspects: critical, cohesive and coping functions. Taking examples from the use of humour during the Holocaust, Morreall firstly, shows how people can rely on comical means to ignite resistance against oppressors or any form of corruption or injustice. Additionally, "research on brainwashing ... has shown that wisecracking humo[u]r may be the single most effective way to block indoctrination" (Morreall 2009, 120). Secondly, humour is beneficial in its cohesive role, which basically fosters group solidarity. Finally, humour is able to help people cope with their traumatic experiences and sufferings. Therefore, apart from illustrating the incongruities that drive Adibah Amin's selected narratives funny, this paper will also highlight the intellectual and moral virtues that lie beneath the humour. 


\section{Incongruities}

Morreall in Taking Laughter Seriously (1983) provides two general types of incongruity: things and presentation. The former involves violations of psychological expectations while incongruities in the latter normally manipulate linguistic patterns. There is no definite list that can summarise all examples of incongruities in both categories as psychological and linguistic expectations are numerous and quite possibly, endless, as they depend on people's flexible capacity of storing, stretching, and adjusting their schemata. Thus, this paper will only select a few examples of incongruity that are frequent in Adibah Amin's narratives. The examples analysed exhibit two major themes of incongruity in things: deficiency and pretence. Out of four types of deficiency listed by Morreall, two that are prevalent in Adibah's texts relate to ignorance/stupidity and moral shortcomings. Under the theme of pretence, this paper will stress on people's inflated opinions of themselves. These two themes however are much related as people's sense of self-inflatedness can also reflect their ignorance/stupidity. It should be noted too that this paper will not discuss the second type of incongruity in detail, which is incongruity in presentation, as the adaptations and modifications of linguistic patterns are much more abundant. Whenever necessary and significant to the analysis however, some explanation involving incongruities in presentation may be included.

Considering that the volumes of As I was Passing (2007a) were originally written as newspapers columns, it is safe to assume that Adibah Amin had taken her Malaysian readers' existing patterns of thoughts and attitude into account while writing them, which means, besides establishing and building up expectations in her texts, she had made use of the expectations readily available in her readers' minds. Hence, locating incongruities in the selected texts in the following section of the paper will show Adibah's significant reliance on existing psychological and linguistic patterns to render her works funny. Another crucial point is that, these texts are in the written form, and the nature of writing has fulfilled the second aspect of humour greatly, whereby readers will be in a play mode. Consequently, this paper will not discuss the second aspect repeatedly throughout the discussion of every selected text to avoid redundancy. When necessary, repetitions are unavoidable. 


\section{Adibah Amin and Humour}

\section{Biography}

Khalidah Adibah binti Amin or better known as Adibah Amin, was born on 19 February 1936 in Johor Bahru, Malaysia, to Amin Sulaiman and Tan Sri Zainun Munshi Sulaiman. The mother, who was also the highly-regarded and admirable Ibu Zain, was one of the leading figures in Malaya's independence movement and a pioneering fighter for women's right to education and politics. Adibah became a professional writer at the age of 14, producing her writings both in Malay and English. She openly asserted that as much as she enjoyed writing in English, her love for the Malay language is unrivalled. Adibah began writing for the New Straits Times in 1971 and later, The Star, in the early 1990s. Besides journalistic and fictional writings, she was actively involved in educational writing, particularly on the English grammar. She also used to translate local and international writings and was awarded the National Translation Personality Award in 2012 (The Star Online 3 October 2012). In the 1970s, the late Tan Sri Lee Siew Yee, the then Editor-inChief of the New Straits Times requested Adibah to author a column for the paper, which was later known as As I was Passing. In 1976 and 1978 respectively, Berita Publishing published two volumes of Adibah's selected pieces from the column. Subsequently in 2007, MPH Group Publishing reprinted her works with the same title. This paper will use the MPH edition as the earlier editions have been out of print.

The following analysis of Adibah's selected writing pieces is discussed thematically. The three main themes are face-saving, self-importance and preservation of stereotypes. In addition to being presented humorously, these themes are selected because they are found to be recurring in Adibah's writings. Under each theme, the analysis will highlight how Adibah utilises the technicalities of humour in the selected texts and how she applies humour to spread intellectual and moral values.

\section{Humour in As I was Passing and As I was Passing II}

\section{Face-saving}

One of the common ways that Adibah uses humour to present incongruities in things is by poking fun at people's idiosyncrasies. Her observations of these idiosyncrasies often centre on how people put in so much effort just to conform to social norms, traditional or modern, at the expense of practicality. One norm on which she frequently narrates is the magnitude of face-saving among Malaysians. The need to save "face" has caused many people to burden themselves and others 
with unnecessary social practices. One of the "face-saving" situations pertains to time management. In "Malaysian time" in As I was Passing, she immediately "attacks" pre-Malaysians' (Malayans') poor sense of time management: "If you were asked to come at 7.30 you just translated it as 8.30 and you were all right" (Amin 2007a, 8). Her instant allusion to the conventional interpretation of time indicates her reliance on readers' pre-conceived notion regarding the matter. The fact that her statement still resonates well in the present may induce smiles or even chuckles among readers, albeit with guilt. Ultimately, what renders this statement incongruous and hence, funny, is her attempt to create an opportunity for readers to laugh at themselves having read a shortcoming with which they can closely identify. This is also reflective of Hobbes's argument in the Superiority Theory, in which people may laugh or smile at this statement because they themselves might have done it in the past. This also describes some part of Morreall's idea of people laughing at their own shortcomings.

Adibah then proceeds to build up her next point by focussing on the dilemma Malaysians face when interpreting time. She prepares readers with some examples to illustrate this ethical dilemma. The most significant part of this text can be found when she begins correlating time management and social status: "In many circles it is an unwritten law that he who is greatest shall arrive last. To arrive after your superior is rude. To arrive before your subordinate is to lose "face"" (Amin 2007a, 10). Having established this recognised tension of socially-defined interpretation of time, she "releases" it through the tale of a man who subjected himself to the gravity of this time-and-status business:

A man I know carries this to painful extremes. When he goes to an office party, he will drive round and round until he sees his immediate subordinate's car there. Only then does he park his car and make his entrance. His car, as you can guess, is a little bigger than his immediate subordinate's and little smaller than his immediate superior's. Once he drove round six times and still the little car was not there. The seventh time he saw, to his horror, that his superior's long, low limousine had arrived.

He swung into a parking space, screeched to a stop, let his wife and me to lock the car and sprinted up three flights of stairs to try and reach the party before his boss. He did not make it. Worse, he could not turn on his subordinate, for the young man had arrived long ago in a friend's car (Amin 2007a, 10).

The humour in this can be attributed to the man's foolishness of allowing himself to be burdened by an absurd practice just to conform to a social norm and to save 
his face, which ironically ended up not the way he had anticipated. In addition, this can be humorous because the man's ridiculous behaviour may reflect what most Malaysians typically do.

Adibah finally ends her narrative with another issue of time management, which relates to the relationship between women's unpunctuality and their idea of femininity. She presents a norm among women to be unpunctual on their dates as it is considered unfeminine to appear "too eager" and that they may take their time to "do" their faces while having men wait for them. This absurd social privilege is often criticised by men and one bluntly points out his doubt on a woman's beauty if she needs to spend so much time preparing herself at the expense of punctuality: “" $[I] \mathrm{f}$ a girl takes so much time to 'do' her face, I'd think it must need a major repair job" (Amin 2007a, 11). This is an example that may represent the social tension between men and women. The final statement can trigger laughter among men, who may have been in the waiting situation, thus agreeing with it, and smiles (or even laugh) among women who are possibly guilty of living up to the expectation.

Another two anecdotes that stress the pressure of face-saving are: "The "face' you must never lose" in As I was Passing and "A small wedding for the fruit of your heart" in As I was Passing II. These two texts are not only similar in the face-saving issue, but also how Adibah makes use of incongruity in presentation to deliver the issue. In the former text, she repetitively translates Malay phrases directly to English, such as "give face" (bagi muka - to show respect), "face water" (air muka - reputation), "drop one's face water" (jatuhkan air muka seseorang - to shame people/to downgrade people's dignity), "to smudge one's face with charcoal" (menconteng arang di muka - to mar one's reputation/dignity) and "wall face" (muka tembok - a shameless person). The "charcoal" reference can also be found in the latter text: "Boyfriend and girlfriend before marriage, then suddenly a marriage. You are smearing our faces with charcoal!"” (Amin 2007a, 102). Additionally, the first part of the excerpt also reflects a colloquial Malay sentence structure, which becomes comprehensible in English only if readers are familiar with Malay linguistic patterns. Furthermore, the title "A small wedding for the fruit of your heart" itself appears funny due to its direct translation of buah hati to refer to one's lover/sweetheart. These witty adaptations of Malay phrases underscore the fact that Adibah really took her readers' linguistic background into consideration while writing.

The latter text also indicates Adibah's application of incongruity in things. She narrates the common practice among Malays who organise grand weddings just for the preservation of honour and reputation despite being financially inadequate. Adibah illustrates this social pressure through a pair of her former students who 
have to succumb to their families' wishes and demands to hold a big wedding. The pair initially is described to be adamant with their decision to have a simple wedding without even an engagement ceremony. Gradually, they face persistent objections from their relatives which eventually force them to comply and get a loan to fund their wedding. Not only does Adibah consider her readers' linguistic patterns in this text to render it funny, she also presents a common social expectation. Moreover, the humour in this text lies in the irony on how the most distant relatives can suddenly be heavily involved in the preparation: "A virgin marry without bersanding?' exclaimed a grand-aunt, four times removed ... And the grandaunts and aunts and cousins of various degrees of removedness exchanged glances and chorused 'What would people say!'” (Amin 2007b, 102).

In all three texts discussed thus far, in reference to Cheetam's argument of "tension/ release of tension", Adibah presents the matter of face-saving as a form of social tension. The expectation to preserve one's "face" is a social pressure felt by most Malaysians. The mere act of reading about it can release the tension. Thus, the cognitive shifts that take place in these texts consist of readers recognising the gravity of face-saving in real life and then reading about it with funny descriptions and situations, which eventually renders the tension release pleasurable. While the situations provided may be familiar to readers and many may have experienced them, the fact that those situations are not taking place as readers are reading the texts, hence fulfilling the spatial and temporal distancing, puts readers in a play mode as they are able to be cognitively and practically disengaged.

Two narratives that can be linked to face-saving without any specific reference to "face" as they put more emphasis on the general notion of upholding reputation and dignity, are "Pompous and proper" and "The peasant look" in As I was Passing and As I was Passing II, respectively. In the former text, Adibah addresses an impulsive, foolish and outrageous inclination against which most people have to fight in order to remain proper in public:

A senior official is worried about an urge that seizes him in the middle of important meetings to pull off his coat and tie and swing his legs on to the table. He has not done it yet, but he has to keep a close watch on himself. A protocol officer confesses that in tense moments when he escorts very illustrious dignitaries across the red carpet he has to fight an impulse to do a wild jig.

A woman leader gets these longings at assemblies after the welcoming committee has sung her praises and hundreds of earnest, respectable ladies await her address. She has to summon all her will power to stop 
herself from saying airily: "Of course, ladies, our fight for equality is a farce."

There is the dignified [cikgu] who yearns to do the shake at students' parties; the small town big shot who pines for the days when he could eat squatting by roadside stalls (Amin 2007a, 280-281).

The images invoked in Adibah's description of the foolish tendencies some people have, can certainly bring amusement in readers. The amusement can also be derived from readers' ability to identify with the irrational urges described, as Adibah even begins the text with a question directed at her readers: "At gatherings where everyone is pompous and proper, are you sometimes tempted to say or do something outrageous?" (Amin 2007a, 280). This very question is able to indicate her consideration of readers' existing psychological patterns when writing the text, which also points to her making use of readers' expectations to immediately render the text humorous.

The incongruities in this text can be found in two ways: first, in the typical images of respectable people who need to remain decorous at all times and the absurd and shocking nature of their impulses; second, in readers' possible identification with the issue discussed and the fact that Adibah writes about it openly. Both forms however can be explained according to the tension-release concept. Peculiar actions are often labelled as "taboos" that need to be curbed. Regardless of one's status and role, people generally are tied to a particular set of do's and don'ts as defined by their community: "But try being a little 'different' in a Malaysian community, and you will get stares and whispers. Continue being 'funny' and people will begin to avoid you and your sisters and daughters may not get any proposals" (Amin 2007a, 281). These social rules which determine and mould people's behaviour are social expectations that can be viewed as a form of tension. Therefore, the constant need to affect pompousness and propriety in public is a pressure felt by most Malaysians, including Adibah herself, as portrayed in the text. The release of tension is facilitated by reading the description of the nonsensical whims that most people have and need to restrain and then being able to relate to the experiences included.

What further renders this release pleasurable is the fact that writing about the issue creates a play mode for readers. While readers may be able to identify with the pressure mentioned above, they are able to be practically unconcerned because of spatial and temporal disengagement established by the writing. Additionally, the idea that readers are not involved in the experiences narrated in the text can also trigger amusement. This text also exudes the third aspect of humour which is 
the sense of enjoyment, specifically the liberating effect. As narrated, peculiarity is considered a social taboo that anyone found being "different" or "strange" can easily get mocked or abandoned. What is liberating about this text is that it stresses on a taboo issue that is rarely discussed. Hence, reading about a social taboo provides readers the chance to release the tension created out of social norms and expectations in real-life situations.

Adibah challenges readers' critical thinking when she pokes fun at Malaysians' adherence to pompousness and propriety just to uphold their reputation. Transgressing this social norm however has a far greater repercussion when such behaviour is claimed to be reflective of one's upbringing which directly alludes to one's parents and family background. Hence, the strict adherence is necessary not only for an individual's sake, but also for the sake of anyone related to him/her: "So, to protect the name of your ancestors, relatives and descendants, you submit meekly to the most suffocating proprieties" (Amin 2007a, 281). Conjuring up funny, illogical images in readers' minds not only induces amusement but allows them to assess the magnitude of this social norm and how it can deprive individuals the chance to be spontaneous and free. Adibah's criticism at the practice is assisted by the use of humour which makes readers more tolerant of the perspective she provides in her writing. Furthermore, she presents a creative way for readers to escape (even momentarily) from the pressure of social norms and expectations, which consequently teaches readers on the positive approach to challenges and problems in life. Morally, Adibah creates a positive space for readers to be more objective of their communities' norms so that they will not be reluctant to change and discard unnecessary and burdening practices and belief.

In "The peasant look", Adibah narrates on the price people are willing to pay, figuratively and literally, just to maintain their reputation. The text reveals the superficiality and irony of people in pursuance of status through the "peasant look" trend, in which the rich ones are seen embracing the peasant-like style. This look nevertheless, cannot appear too real as being mistaken for actual peasants will certainly mar one's reputation, which is the exact opposite of what these people aim to achieve: "To do the Peasant Look so well that you pass for a genuine peasant, no-lah, like that cannot-lah. Whole life sweat to get status simply to throw awaykah?" (Amin 2007b, 167). Adibah then invites readers to imagine the peasant look in Malaysian contexts:

The Rubber Tapper Look alone would have several versions. You could go to the next function wearing fashionably faded sarong and kurung, sarong and half-sari, sari blouse and long skirt, or samfoo with long gloves and headscarves. 
For the Farmer Look you could have, among others, the samfoo with knee-length trousers and conical-top-wide-brimmed bamboo leaf hat, the baju Kedah with sarong lifted knee-high, the baju kurung or kebaya with sarong ditto and headgear in brilliant orange Kelantan batik. All artistically torn and tattered, of course. I cannot wait to burst upon the office scene wearing one of these.

Then there would be the Fisherman's Look, the Tin Mine Labourer's Look, the Coconut Climber's Look, the Construction Worker's Look. The second last would be ideal for committee meetings in old government buildings where the air conditioning keeps failing. The last would help when you feel and look a wreck from the night before, for the wide scarf secured to the hat covers all but your eyes (Amin 2007b, 167-168).

This text certainly does not fall short of humour and sarcasm. Readers can indeed find themselves, (guiltily for some) enjoying, the ironies presented all the way through it.

Humour in this text hence, can be attributed to several facets. Firstly, with the narration of the abovementioned ironies, the incongruity element is too apparent to ignore. The notion that more and more wealthy people fork out their money just to appear "peasant-like" in keeping with the latest trend, while preserving their social status, is the greatest form of irony, from which readers can barely afford to look away. Without having to explain how luxury looks like, it is safe to state that Adibah has taken her readers' existing psychological patterns into account, as reading about rich people's affirmative reaction to the peasant look, internalising and visualising the image of peasant-like luxury and discovering the exorbitant price of the "peasant" clothes, not only violate the image of sophistication and luxury that is typically associated with them, but also betray people's shallowness, hypocrisy and futile affectation.

These incongruities nonetheless can result in amusement because it fulfils the exhilarating and liberating aspects of enjoyment. It is exhilarating in the sense that readers get to change their existing expectations of rich people and view them in a new light, and liberating in that those who cannot afford the peasant clothes but already have them in possession, as their daily attire and also for much cheaper prices, may feel baffled by the superficiality and idiocy of those who aspire and spend to look like peasants. It is in this respect too, that the tension-release concept is applicable. Social status comes with corresponding social expectations, which undeniably become sources of tension. To read about people who belong to the higher part of social hierarchy spending so much to look like those of the lower 
strata allows people of the latter group to escape from the tension created by the existence of social status and laugh at the absurdities shown by the former group.

Intellectually, Adibah uses humour in this text to make people think of the irony embraced by many people just to conform to a social norm, no matter how ridiculous the norm is. In the following excerpt, she wittily presents oxymoronic notions that are rampant among the affluent: "'Peasant' ensemble, a few hundred dollars; 'wind-blown' hairstyle and 'outdoor' complexion, a few hundred more in cosmetics and expertise, for nothing is so costly to create the "natural' look" (Amin 2007b, 166). She then points to the hypocrisy and contradictions that some people exude: "You do not want to look too authentic, lest even for a fleeting moment you be mistaken for the real thing" (ibid.). Morally, the humour in the text makes way for people to transcend their personal concern and pride, and learn to evaluate their behaviour and surroundings. Most importantly, it creates a nonthreatening situation that allows readers to be less defensive and more open to criticism. Consequently, readers are able to discover the absurd practice done in the name of social status and be humbled by the discovery.

\section{Self-importance}

Apart from pointing out incongruities in Malaysians' or Malays' social norms and actions, Adibah also has a knack for informing and questioning idiosyncrasies among humans in general. In "P.J. pollution and Martian muck" in As I was Passing and "They've styles, those space beings" in As I was Passing II, she narrates on people's sense of self-importance. In the former, initially she correlates humans' irresponsible polluting behaviour with the absurd need to assert and declare power:

The urge to pollute must be related to some profound human need the need to leave our mark, perhaps, to prove to everyone including ourselves that we exist and have been "there". To show unimpressed nature too who is master. Fresh air, green grass, white sands, clear waters - they provoke us unbearably. We cannot rest until we have filled the air with smoke, strewn bits of paper on the grass, left picnic remnants to rot on the sand, dumped oil and seven types of filth in the waters (Amin 2007a, 47).

She further highlights our flawed tendency to close one's eye to local problems but ironically, be wide awake to any slightest evil beyond our reach:

The glow of virtue one gets from correcting evils in someone else's country. Ah, to improve the health of the Hottentots, the politics of the Polynesians, the education of the Eskimos! 
Besides it is harder to see evils in one's own country. One grows up breathing the smog, as it were, and imagines it is normal fresh air. But let there be pollution in another land - how clearly one would see it, how coolly expose and analyse it, how courageously starts a movement to clean it up.

So do not talk to me about K.L.-P.J. pollution, I do not see it, though sometimes I choke on it and wonder why. Stink in Saigon, rubbish in Riyadh, any time. Perhaps soon, muck on the moon or Mars. I cannot hope to qualify for the clean-up expedition, but that will not stop me spinning out solemn armchair articles about it awaken the world's conscience ... Chimborazo, Cotopaxi, let us sweep your sampah away! (Amin 2007a, 49).

In “They've styles, those space beings", again, sarcastically, she stresses humans' inflated sense of ego that often renders us proud but ignorant: "The fact is we have always nursed a fond conviction that, science fiction apart, no creature could surpass us in intelligence. Nor in physique either" (Amin 2007b, 190). In this text too, like "P.J. pollution and Martian muck", she brings to light our ironic inclination to dismiss or ignore problems in our own land (or planet), and be more concerned and preoccupied with matters beyond our (terrestrial) grip instead:

Funny creatures, we humans. We have not begun to solve earth's problems and already we are peering into the heavens. We continually misunderstand one another, yet we dream of inter-planetary rapport. No wonder the superbeings do not deign to call on us though they could, quite easily, through their "black holes" top speed transit system (Amin 2007b, 192).

Readers are presented with two incongruous states: the expectation that prescribes how people should behave and treat their lands/planet, particularly those within reach, and the undesirable reality that portrays people's conceited sense of heroism and hypocrisy in selective charity, concern and awareness. While the presence of these contradictory situations can build up tension as they signify and attack humans' self-proclaimed impression of superiority, Adibah's comical way of presenting the situations is able to release the weight of the tension. The sense of "guilty pleasure" induced while reading these texts then, is the cognitive shifts that readers may experience.

The fact that these human ironies are presented in writing distances readers from their immediate moral and practical concerns. The writing medium creates a non-participative aspect that allows readers to be in a play mode. Thus, although readers may find these ironies in themselves, they can still find reading about them 
pleasurable and amusing. The enjoyment can also rely on the texts' liberating effect. Essentially, Adibah addresses an issue that is generally known but rarely discussed. The negative notion of selective kindness and misplaced concern is easily eclipsed by the normally-celebrated positive values of offering a helping hand and exploring new knowledge, territories and potentials. To have Adibah stress and question this hypocrisy gives readers a chance to escape from the highly cushioned and padded comfort zone that is shaped by social expectations and norms.

The use of humour in these texts is indeed beneficial in some ways. Adibah's direct criticism at human hypocrisies in the texts instantly hones readers' critical thinking. Readers are made to realise the undesirable reality of human ironies that themselves may possess, which subsequently trains them to expand and deepen their understanding of what "doing good" and "human exploration" mean. Morally, Adibah utilises humour to make readers more aware of human shortcomings that should in effect, humble them. Both texts plainly describe humans' inflated sense of ego that paradoxically merely reflects our ignorance, foolishness, baseless competitiveness and destructive instincts.

\section{Preservation of Stereotypes}

"Getting Malaysia on the map" and "Tourist notions" in As I was Passing are humorous anecdotes that highlight the phenomenon of "preservation of colonial and orientalist stereotypes". In the first text, Adibah touches on the changing identities and images between Malaya and Malaysia. Despite the changes taking place, there is this tendency among foreigners to view Malaysia and the people through colonial and orientalist viewpoints that preserve and exoticise us in primitive images and ideas:

I still have a letter from an English pen-pal I had in 1948. "I wish," she wrote in her round 12-year-old handwriting, "I was with you in Malaya with all those tigers and snakes and crocodiles." Writing back, I added out latest attraction, the new jungle men. I did mention they had modern weapons just like in the West, but she has it firmly fixed in her mind that they used parangs and blowpipes (Amin 2007a, 39-40).

Most of these Westerners' ludicrous ideas are undoubtedly affected by Western films such as The Jungle Princess (1936) or their reading of Malaya in the colonial days such as the works of Somerset Maugham: "I have told you, have I not, of the girl tourist who was inconsolable because the Malaysian men she met were not half as deadly as Somerset Maugham promised?” (Amin 2007a, 39). 
In "Tourist notions", Adibah continues to narrate on the Westerners' ignorant inclination to generalise, homogenise and continuously define us according to their rigid, colonial-influenced, orientalist blanket point of view:

Then there are the tourists who come with visions of an exotic and primitive Malaysia and feel cheated by the prosaic modern reality.

They like to think of Malaysians watching wayang kulit or doing the dragon dance or walking on live coal for entertainment and are disappointed to find them flocking to cinemas, nightclubs and restaurants like dull Westerners.

One girl was very cut up because I could not show her a single monkey plucking coconuts. She had seen pictures of this and thought it was our standard way of bringing down coconuts for our copra trade (Amin 2007a, 43).

Readers may find both of these anecdotes humorous in the ignorance or stupidity exuded by some Western visitors/tourists. Reading about the outdated or nonsensical images and ideas that some Westerners have of us makes us feel amused at their unbelievable degree of ignorance despite being commonly heralded as "modern", "highly civilised" and "most advanced". Additionally, their attempts to "keep" us in our jungles and exoticise our appearances and behaviour appear funny because we are completely aware of our own conditions and that they certainly do not reflect their absurd expectations. The cognitive shifts therefore, come from two main sources: first, between the common expectation that sets them as people who are more advanced in knowledge and the ignorance that they exude; second, between their persistent and highly imaginative exoticising attempts and the modernity that we have increasingly embraced. Morally, Adibah uses humour in these two texts to trigger and sustain resistance against any vilifying act, be it through writing or action, which can deprive us of our own identity. Consequently, this can trigger the cohesive effect of humour, which fosters solidarity among Malaysians.

\section{Conclusion}

It is interesting to note that an element that is easily and frequently overlooked because of its non-serious trait, its "lightness", as a matter of fact, can be used as a strategy for critical and serious purposes. Humour in Adibah Amin's selected texts in both volumes of As I was Passing has proved to be more than just an inducer of smile or laughter. This paper has, firstly, shown how Adibah includes some elements fundamental to humour in her writing, which are the presence of 
cognitive shifts that involve expectations and violation thereof, the play mode that induces practical disengagement, and the sense of enjoyment that is exhilarating and liberating. Having identified the aspects that render Adibah's texts humorous, this paper then exposes the positive side of humour of which Adibah has made use, by highlighting the intellectual and moral values. Besides pointing out the incongruities in things that deal with transgression of psychological expectations, this paper also illustrates Adibah's application of incongruities in presentation in her writing, showing her comical adaptations of linguistic patterns, that further proves her astute use of humour. Therefore, it is hoped that this paper will initiate and inspire further interest to critically examine Adibah Amin's long marginalised and forgotten English writings.

\section{Acknowledgements}

The authors would like to thank International Islamic University Malaysia for the research grant provided under the Research Initiative Grant Scheme (RIGS), with the grant number RIGS16-239-0403.

\section{Note}

1. In an interview in 1995 she acknowledged, "I think and feel in Bahasa ... I dream in Bahasa and writing in English is just an attempt" [as quoted in Nor Faridah and Quayum $(2003,232)]$.

\section{References}

Amin, A. 2007a. As I was passing. Petaling Jaya: MPH Group Publishing Sdn Bhd. . 2007b. As I was passing II. Petaling Jaya: MPH Group Publishing Sdn Bhd.

Cheetam, D. 2003. Written humour and humour theory. English Language and Literature 40: 65-94. http://www.academia.edu/1060417/Written_Humour_and_Humour_ Theory (accessed 20 February 2017).

Ganesan, K. 2016. British colonial education and the rise of nationalism in Malaya: Tracing the route of the Merdekal generation in Adibah Amin's This End of the Rainbow. Anglica: An International Journal of English Studies 25(1): 233-253.

Morreall, J. 1983. Taking laughter seriously. New York: State University of New York Press.

. 2009. Comic relief: A comprehensive philosophy of humor. United Kingdom: Wiley-Blackwell. https://doi.org/10.1002/9781444307795

Nor Faridah, A.M. and Quayum, M.A. 2003. Colonial to global: Malaysian women's writing in English 1940s-1990s. Kuala Lumpur: International Islamic University Malaysia Press. 
NST Online. 5 May 2016. Facebook opens office in Malaysia. https://www.nst. com.my/news/2016/05/143684/its-official-facebook-opens-office-malaysia (accessed 1 March 2017).

Quayum, M.A. 2008. Interrogating Malaysian literature in English: Its glories, sorrows and thematic trends. Kunapipi 30(1): 149-168. http://ro.uow.edu.au/kunapipi/vol30/ iss 1/13 (accessed 22 February 2017).

. 2014. Malaysian literature in English: Challenges and prospects in the new millennium. In One sky, new horizons: Studies in Malaysian literature in English, ed. M.A. Quayum, 33-51. Singapore: Marshall Cavendish.

Sorensen, M.J. 2008. Humor as a serious strategy of nonviolent resistance to oppression. Peace \& Change: A Journal of Peace Research 33(2): 167-190. http://onlinelibrary. wiley.com/doi/10.nn/j.1468-0130.2008.00488.x/full (accessed 22 February 2017).

The Star Online. 3 October 2012. Adibah Amin awarded National Translation Personality Award 2012. https://www.thestar.com.my/news/nation/2012/10/03/adibah-aminawarded-national-translation-personality-award-2012 (accessed 15 February 2018). 